\title{
ANALYSIS OF THE PERCEPTIONS OF CRIME AGAINST TOURISTS IN FLORIDA ROAD, DURBAN - REPUBLIC OF SOUTH AFRICA
}

\author{
Madiseng M. PHORI* \\ Tshwane University of Technology, Department of Tourism Management, Pretoria, South Africa, e-mail: PhoriMM@tut.ac.za \\ Charlotte MBALI \\ Durban University of Technology, Faculty of Management Sciences, Durban, South Africa, e-mail: mbalivc@gmail.com
}

Citation: Phori, M.M, \& Mbali, C. (2020). ANALYSIS OF THE PERCEPTIONS OF CRIME AGAINST TOURISTS IN FLORIDA ROAD, DURBAN - REPUBLIC OF SOUTH AFRICA. GeoJournal of Tourism and Geosites, 31(3), 1166-1173. https://doi.org/10.30892/gtg.31331-554

\begin{abstract}
The goal of the study was to investigate the perceptions of selected stakeholders on crime against tourists eating out at Florida Road in Durban, Republic of South Africa (RSA). It is known internationally that South Africa has high crime rates, and those working in the tourism and hospitality industry there may fear that this will cause decline in tourists. Florida Road was chosen as location for the research because it is an open tourist spot (not contained, exclusively for tourists, like cruise ships or safari tours) and therefore more vulnerable to direct targeting by criminals. The research paradigm was both quantitative and qualitative. The study was grounded on psychosociological theories in criminology such as Social Disorganisation Theory and Hot Spot Theory to look into the issue of victimisation of tourists. Analysis of the perceptions of stakeholders revealed that theft is the most frequent crime. There has been a decline of customers, but some think this may be due to global economic decline. Discussion with the Urban Improvement Precinct Forum revealed various security measures, both enacted and proposed, with business in partnership with the police. These are costly, but stakeholders consider they are necessary to improve the security of the road. The study concludes that safety and security are important factors to consider for tourism growth as tourists are more likely to choose a destination perceived to be safe.
\end{abstract}

Key words: perceptions, tourists; crime, safety, security, Florida road, UIP

$* * * * * *$

\section{INTRODUCTION}

One of South Africa's province, KwaZulu-Natal [KZN] has the most beautiful, scenic and natural landscapes that attract both domestic and international tourists, yet crime is the biggest threat for tourism growth since people will be discouraged from visiting the province (Nkosi, 2010). Levantis and Gani (2000) tested the effect of crime on the demand for tourism across eight developing nations of the Caribbean between the period 1970 and 1993. They found that if a nation is suffering a deteriorating law and order problem relative to other nations in the region, then the demand for tourism to that nation will be adversely affected. Although the number of tourists visiting South Africa has been increasing, serious concerns have been raised about the level of crime in the country (Moyo and Akanbi, 2013).

In the media, South Africa is listed among the world's most violent nations outside a war zone and is also regarded as the rape capital of the world (Ferreira and Harmse, 2000). Nkosi (2010) states that tourism industry in South Africa has become one of the leading economic contributors to the country's economy. South Africa received 9.2 million international tourists in 2012 which saw the industry grow by $10.2 \%$. This figure was significantly higher than the global average growth rate of $4 \%$ during the same year (South African Tourism, 2013). However, in 2014 the total number of foreign travellers who visited South Africa from Africa, overseas and unspecified countries, arriving through all ports of entry was 15092 016. The 2014 figure represents a decrease of $0.4 \%$ as compared with the 2013 figure of 15154991 (Statistics South Africa, 2015). The country witnessed a 12.8\% increase in international tourists from 8.9 million in 2015 to 10 million in 2016 (South African Tourism, 2017). Domestic tourism revenue increased by 12\% to total R26.5 billion in 2016, compared to R23.6 billion in 2015 (South African Tourism, 2017). On average, domestic tourists in this period increased by spending per trip than in previous years. According to Goodrich (2002), the negative image formed through the lack of safety and security may harm the tourism industry due to negative word-of-mouth communication, regardless of the first-class visitor attractions have on offer at the destination. George (2003) states that tourists prefer to feel safe during their visit to a destination, so security issues become a competitive point between many tourist destinations. Safety and security of a destination plays a central role in a tourist's decision-making process (Ferreira and Harmse, 2000). Pizam (1999) indicates that crime with a potential risk to personal safety contribute to a tourist's perceptions of safety and security to a particular destination. In addition, tourists are most likely to choose a destination which is perceived to be the least dangerous (Sönmez and Graefe, 1998). Even if there are no statistics specifically focusing only on crime against tourists, the Africa Check website (2020) shows that in 2013 and 2014 South Africa experienced two of the worst years in the last decade with violent crimes such as murder and attempted murder going up by $3.5 \%$ and $3.2 \%$ respectively. Robbery with aggravating circumstances drastically increased by $11.2 \%$ for the same period.

These statistics have also revealed that the current South Africa's murder rate is five times higher than the 2013 global average. The website further shows that there has been an increase of over 5\% in all categories of robbery over the past year. After a four year period, a total of 2.12 million crimes were recorded in 2017 and the 2.09 million recorded in 2018 (Business Tech, 2018).

Moyo and Akanbi (2013) found that crime levels are significant determinants of tourist inflows into South Africa. In a previous study by Nkosi (2010), it was revealed that people are aware of the levels of crime against tourists and as a result they will not visit tourism facilities with a history of crime. According to Perry and Potgieter (2013) crime in relation to tourism processes should be considered as part of broader strategies that incorporate risk and safety. All stakeholders in tourism should join forces in fighting crime.

\section{LITERATURE REVIEW}

Tourism and crime in South Africa

In recent years, tourism has emerged as an important part of economic growth in South Africa and the world and it is one of the leading

\footnotetext{
${ }^{*}$ Corresponding author
} 
sectors of the service industry and a major constituent of the world economy (Hermann et al., 2012), worldwide, tourism is regarded as the industry with the highest growth rate and the greatest potential for job creation. As indicated by Herbig (2008), South Africa as a developing country currently faces challenges in many areas including crime and criminality.

The perception that South Africa is one of the world's crime capital remains and while crime rates in specific types of crime are decreasing or stabilising, there continues to be an upward trend in many type so crimes (Perry et al., 2012). As indicated by Phori (2017) safety and security in a destination is the second most important purchase criterion after value for money for South Africa's target consumers across all priority markets.

\section{Safety and security in Florida Road \& the UIP}

Although Florida Road benefited from the 2010 Soccer World Cup infrastructure upgrade, the area was experiencing increasing levels of urban decay, specifically around the issue of crime as indicated by the Florida Road Urban Improvement Renewal (2020). Florida Road's biggest challenges have been car guards and vagrancy and these have affected every aspect of the road, from perceptions of safety, to the poor quality of visitor experience as reported by Jacobs (2016). Although an integral part of Durban life, car guarding is illegal and poses a number of challenges like intimidation, and crimes such as remote jamming and vehicle theft.

This was negatively impacting on property values/rates base, investor confidence, business viability and the quality of life of those who work, live and visit the area (Florida Road UIP, 2020). The UIPs have been implemented abroad and throughout South Africa to tackle the threat of urban decay, retain existing investment, stimulate new investment, improve safety and quality of life and respond to the challenge of environmental sustainability. In KwaZulu-Natal, this structure is known as a UIP or Special Ratings Area [SRA] and is classified as a geographic area within which the majority of property owners agree to pay for certain services supplementary to those supplied by the municipality. The Florida Road Urban Improvement Precinct [UIP] has a proactive approach to security, with the focus of identifying possible criminal intent before it occurs and taking corrective action (Florida Road UIP, 2020).

\section{Theoretical framework of crime against tourists}

Tourism establishes an interactive relationship among different elements: the tourist, the place, local residents, the tourism industry and services in general (Brás, 2015). Its growth leads, in most destinations, to a significant increase in security incidents, since it provides more opportunity for crime, especially economic crimes (e.g. theft, fraud) but also crimes involving physical or sexual assault, among others. Various psychosociological theories in criminology have been developed in recent years and therefore the study will be grounded on theories such as Social Disorganisation Theory developed by Shaw and McKay (1942) and Hot Spot Theory by Sherman et al. (1989) to look into the issue of victimisation of tourists.

\section{Social Disorganisation Theory}

According to Shaw and McKay (1969), Social Disorganisation Theory (SDT) advocates that criminal behaviour is not caused by issues at the individual level, but rather caused by the inability of a community structure to realise the common values of its residents and maintain effective social control. Sampson and Groves (1989) also shows that lack of supervision, lack of community involvement, and reduced friendship and other social networks are the primary cause of crime and disorder in the neighbourhood. Brás (2015) contends that criminal activities in tourist destinations are linked in large part to ethnic heterogeneity and urban growth in specific seasons (seasonality). It is evident that when a community is socially disorganised due to urban growth, it will expose a lower capacity for social control and for engaging in socio-cultural activities with tourism, which can potentially lead to increased criminal activity.

\section{Hot Spot Theory}

Crime hot spots are small areas with high crime densities (Chainey et al., 2008). Sherman and Weisburd (1995) defines crime hot spots as "small places in which the occurrence of crime is so frequent that it is highly predictable, at least over a one year period." Ryan and Kinder (1996) call these areas 'criminogenic' locations, where tourists and criminals converge, and where there is a grea ter exposure to risk and insecurity and, in most cases, an insufficient number of police to ensure the safety of tourists. The Hot Spot Theory considers that a series of conditions are generally unified to make tourists an easy target for crime: The accidental tourist (being in the wrong place at the wrong time); The tourist industry provides victims (due to lack of information about criminogenic locations); The tour ist is seen as a specific target because of the ease of carrying out the crime and the low probability that an official report will be made; The tourist is considered by the criminal to be a legitimate target because tourists are seen as symbols of global capitalism, thereby making it justifiable to commit crimes against them.

\section{RESEARCH METHODOLOGY}

The goal of the study was to investigate the perceptions of selected stakeholders on crime against tourists eating out at Florida Road in Durban. Florida Road was chosen as location for the research because it is an open tourist spot (not contained, exclusively for tourists, like cruise ships or safari tours) and therefore more vulnerable to direct targeting by criminals. The motivation for this study arose out of awareness that the growth of tourism can be hampered by fears of crime on tourists. The study was about perceptions not actual counts of reported crime. The focus on crime statistics would not correctly reveal actual counts of crime in Florida Road as that is only part of a South African Police Services 'precinct' for the statistics. Furthermore, the researcher could not get actual tourist perceptions as nobody wants to discuss fears of crime while on holiday. The study used perceptions from hospitality workers, roadside car-guards, taxi operators who bring visitors to the area, law-enforcement agencies and the hospitality business managers in the area. These units of analysis were chosen as they work in Florida Road and interact with tourists on a daily basis and have knowledge and observed criminal activities against tourist in the study area.

The study is descriptive in nature as it seeks to clarify the defining characteristics or properties of people, events or problems (Cooper and Schindler, 2001). McNabb (2002) adds that data from descriptive research may be qualitative or quantitative. Therefore, the research paradigm was both quantitative and qualitative. This approach has been adopted for the purposes of this study to establish the perceptions of crime on tourists eating out at Florida Road in Durban.

The empirical study consisted of two surveys $(\mathrm{N}=75)$, interviews $(\mathrm{N}=5)$ and focus group discussion $(\mathrm{N}=8)$. The first survey was conducted to gain understanding of perceptions of crime against tourists and the behaviour of tourists in general in relation to safety and security in Florida Road from the hospitality workers and security or taxi drivers and the second survey was carried out to understand what the law-enforcement agencies and the business owners are doing to fight the issues of crime against tourists. 
Interviews and focus group discussion with key informants from law-enforcement agencies and hospitality business managers/owners were also used as interpersonal contact with key informants is important as it allows an opportunity to follow-up on interesting comments. The collected data was analysed using interpretative phenomenological analysis as the study attempts to understand people's perceptions, perspectives and understandings of crime against tourist. The study is based on convenience sampling which is a type of non-probability sampling technique appropriate to a descriptive study. The data collected was processed using the Statistical Package for Social Sciences (SPSS) and NVivo software programmes.

\section{RESULTS \& DISCUSSIONS}

\section{Results of Quantitative Study from Hospitality Workers, UIP Security Guards \& Taxi Drivers}

The data was successfully collected from 42 respondents of which 32 were hospitality workers and 10 were security or taxi drivers. The number of responses varied for some of the questions since one of the groups did not have the same variables. Interpretation of data plays an important role in research as it is the process that brings meaning to the views of the respondents. The processing of the results was provided through the SPSS software programme to generate tables and charts for closed-ended questions and Nvivo for open-ended questions of the survey.

Respondents were profiled based on their demographic characteristics with issues under consideration being gender, age and education levels. This was to ascertain if any of these characteristics will make differences in their perceptions. The study also looked at different perceptions between hospitality workers and taxi drivers as they might not have similar experiences when interacting with visitors in the area.

The results show that majority of security guards and taxi drivers perceive crime as a weekly occurrence whereas hospitality workers see it as a monthly occurrence. The reason that the transport workers perceive more of this crime than the hospitality workers is probably because the hospitality workers are so preoccupied by their indoor work so they do not really see the incidents so often. Slightly more than half of the respondents $(53 \%)$ perceive Florida Road as safer than other areas they know in Durban. This suggest that some of the security arrangements put in place in the area are perceived to be working better than in those other areas. This is not surprising as there is more investment by SAPS, eThekwini Metro Police and UIP in Florida Road security.

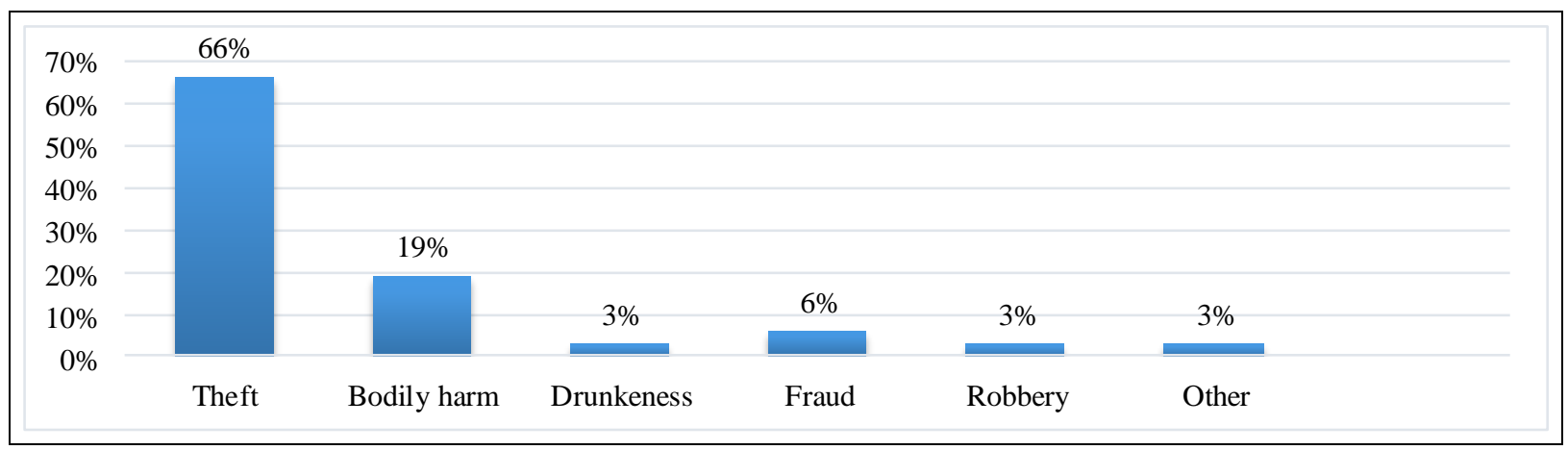

Figure 1. Perceptions on type of criminal activities

According to the data presented on Figure 1 above, the respondents were asked about the perception regarding the type of criminal activities along the Florida Road and top on the results was theft which contributed largest with $66 \%$, assault was second with $19 \%$, fraud $6 \%$ while public drinking robbery and other contributed 3\% each.On other hand, the female respondents with $72.2 \%$ are in agreement with the $100 \%$ of respondents aged between 41-50 (Table 1 below) and the 76.9\% with diploma qualification that theft is the most frequent type of crime committed at Florida Road. This presented evidence that the more academically qualified respondents the more understanding of the types of crime happening in the area and also this suggests that females are likely to be victims of crime than their male counterparts.

Table 1. Age and type of Crime

\begin{tabular}{|c|c|c|c|c|c|c|c|c|}
\hline \multirow{2}{*}{ AGE } & \multicolumn{6}{|c|}{ What types of criminal activities are recorded in Florida Road? } & \multirow{2}{*}{ Total } & \multirow{7}{*}{$\begin{array}{l}\text { Theft appears to } \\
\text { be most perceived } \\
\text { criminal activity } \\
\text { reported in Florida } \\
\text { Road across all } \\
\text { different age } \\
\text { groups. }\end{array}$} \\
\hline & Theft & Bodily harm & Drunkenness & Fraud & Robbery & Other & & \\
\hline $21-30$ & $70.8 \%$ & $20.8 \%$ & $4.2 \%$ & $4.2 \%$ & & & $100 \%$ & \\
\hline $31-40$ & $50.0 \%$ & $16.7 \%$ & & $16.7 \%$ & $16.7 \%$ & & $100 \%$ & \\
\hline $41-50$ & $100 \%$ & & & & & & $100 \%$ & \\
\hline $51-60$ & & & & & & $100 \%$ & $100 \%$ & \\
\hline Total & $65.6 \%$ & $18.8 \%$ & $3.1 \%$ & $6.3 \%$ & $3.1 \%$ & $100 \%$ & $100 \%$ & \\
\hline
\end{tabular}

Table 2 below shows that $88.9 \%$ of the female respondents indicated that local visitors are more affected as compared to their international counterparts. This postulate that local visitors become more complacent while on vacation in their own country while on the other hand international visitors take more precautionary security measures seriously while on holidays.

Table 2. Gender and Victims

\begin{tabular}{|c|c|c|c|c|}
\hline GENDER & Which of these people are more affected by crime in Florida Road? & Total & $\begin{array}{c}\text { More females believe } \\
\text { local visitors are more }\end{array}$ \\
\hline Male & $50.0 \%$ & $50.0 \%$ & $100 \%$ & $100 \%$ \\
\hline Female & $88.9 \%$ & $11.1 \%$ & $100 \%$ & affected by crime \\
\hline Total & $71.9 \%$ & $28.1 \%$ & $100 \%$ & \\
\hline
\end{tabular}

As shown in Table 3 and 4 below, $69.2 \%$ of respondents amongst hospitality workers, UIP security guards and taxi drivers aged 2130 indicated that the safety and security of visitors in the area is fair and the $100 \%$ with degree qualification indicating that the safety and security of visitors in the area is good. This suggest that in general people felt safe when they are in Florida road and this can be attributed to the UIP model implemented in the area. 
Table 3. Visitor Security

\begin{tabular}{|c|c|c|c|c|c|c|}
\hline AGE & \multicolumn{2}{|c|}{ How do you find the safety and security of visitors in the area? } & Total & \\
\hline & Excellent & Good & Fair & Poor & $\begin{array}{c}\text { Majority of } \\
\text { respondents aged } 21- \\
30 \text { perceive safety } \\
\text { and security of } \\
\text { visitors as FAIR }\end{array}$ \\
\hline $31-40$ & $7.7 \%$ & $15.4 \%$ & $69.2 \%$ & $7.7 \%$ & $100 \%$ \\
\hline $41-50$ & $50.0 \%$ & $18.2 \%$ & $54.5 \%$ & $27.3 \%$ & $100 \%$ \\
\hline Total & $33.3 \%$ & $60.0 \%$ & & & $100 \%$ \\
\hline
\end{tabular}

Table 4. Education and Security

\begin{tabular}{|c|c|c|c|c|c|c|}
\hline EDUCATION & \multicolumn{4}{|c|}{ How do you find the safety and security of visitors in the area? } & Total & \multirow{6}{*}{$\begin{array}{c}\text { Majority of } \\
\text { respondents with } \\
\text { Degree education level } \\
\text { perceive safety and } \\
\text { security of visitors as } \\
\text { GOOD }\end{array}$} \\
\hline & Excellent & Good & Fair & Poor & & \\
\hline High school & $12.0 \%$ & $16.0 \%$ & $56.0 \%$ & $16.0 \%$ & $100 \%$ & \\
\hline Diploma & $7.7 \%$ & $7.7 \%$ & $76.9 \%$ & $7.7 \%$ & $100 \%$ & \\
\hline Degree & & $100 \%$ & & & $100 \%$ & \\
\hline Total & $9.5 \%$ & $21.4 \%$ & $57.1 \%$ & $11.9 \%$ & $100 \%$ & \\
\hline
\end{tabular}

The results of the descriptive analysis revealed that the number of tourists has decreased at Florida Road in the last three years due to crime and the area is currently experiencing high level of theft of motor vehicles and theft out of motor vehicles as evidenced by both the actual precinct statistics and the perceptions of the workers. The study further revealed that the decline of visitors in the area may be influenced by factors other than crime, such as global economic downturn. The respondents were asked to indicate what influenced criminal activities in Florida Road. As indicated in Figure 2, lack of police support was top with 35.5\% of the respondents and that restaurants do not care for their visitors was second with $32 \%$ of responses. Other factors included too many hawkers $16 \%$, visitor negligent of warning signs $13 \%$ and $3 \%$ shows that criminals take advantage and commit crimes when street lights are off in the area.

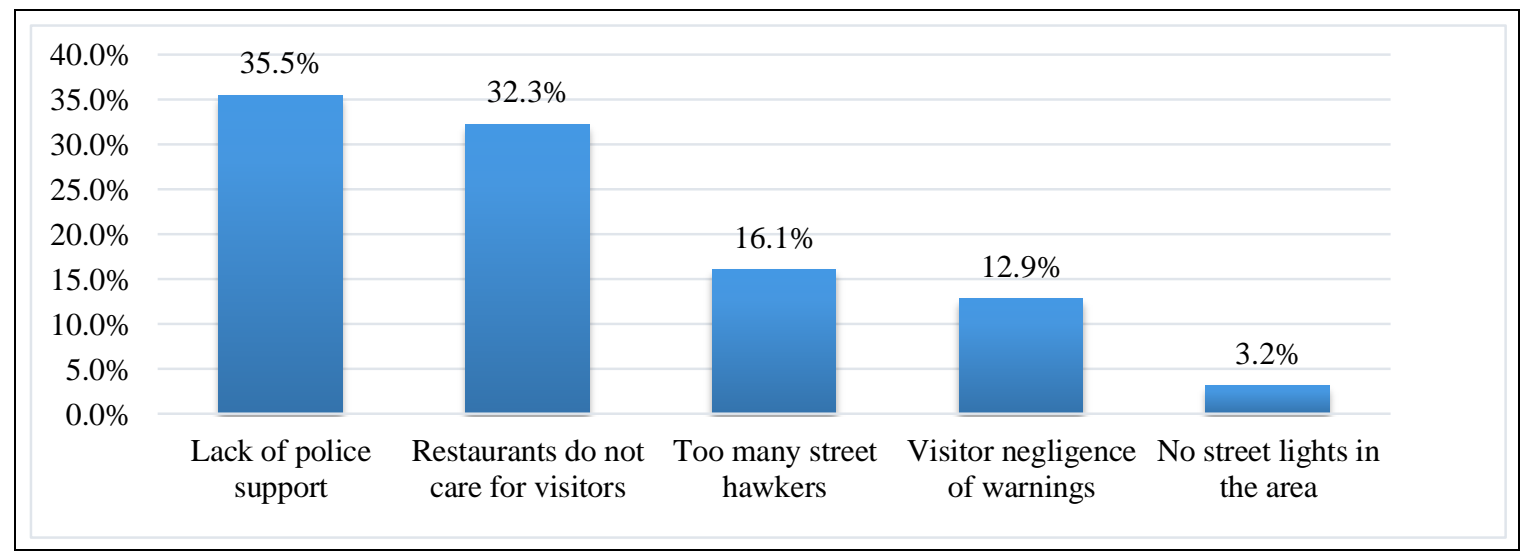

Figure 2. The influence of crime in Florida road

\section{Inferential Statistics}

A statistical Pearson Chi-square test was further conducted to ascertain if the respondents' perceptions had any correlations with certain variables such as age, gender and education levels. As evident in Table 5 below, there were no significant statistical differences $(p<0.05)$ in the scores between these three variables and most perceptions. However, results that are significant of the chi square tests are highlighted in red in Table 5 below.

The p-value between 'age' and 'a perception on type of criminal activities' is 0.001 , which is less than the level of significance of 0.05 . This has revealed that the age group of 31-40 perceive majority of types of criminal activity take place in the study area than any other age group. The various age groups had different opinions on this perception; this means that the age of the respondent did play a significant role in terms of the perceptions on type of criminal activities in Florida Road.

The p-value between 'gender' and 'visitors affected by crime in Florida Road is 0.015 , which is less than the level of significance of 0.05. More female respondents perceived that local visitors are more affected by crime in the area as opposed to international visitors. This means that each gender had significantly different opinions on the type of visitors most affected by crime.

The p-value between 'gender' and 'general security in the area and security of visitors is 0.046 , which is less than the level of significance of 0.05 . Majority of respondents who are females perceived the general security in the area as poor whereas the males perceived it as good. This means that each gender had significantly different opinions about the general security of the area.

The p-value between 'education' and 'general security in the area and security of visitors is 0.007 , which is less than the level of significance of 0.05 . Majority of respondents with high school and diploma qualifications perceived the general security in the area as fair whereas those with degrees perceived it as good. This means that the various education groups had different opinions on this perception. A significant relationship exists between education levels and perceptions of the general security in the area and security of visitors.

\section{Results of Quantitative Study From Law-Enforcement Agencies And Business Owners}

The data was collected from 33 respondents of which 12 were law-enforcement officials and 21 being business owners or managers. The number of responses varied for some of the questions since one of the groups did not have the same variables. The Hot Spot Theory informed us that a series of conditions are generally unified to make tourists an easy targ et for crime and one of those conditions is that the tourism industry provides victims due to lack of information about criminogenic locations. The study shows that $69 \%$ of respondents 
indicated that the common crimes against person in Florida Road are robbery, with $25 \%$ of respondents being worried about mugging and $6 \%$ for assault. Property-related crimes which included housebreaking, theft of motor vehicle, theft out of or from motor vehicle, fraud and shoplifting were also of a concern to the respondents.

Table 5. Pearson Chi square tests

\begin{tabular}{|c|c|c|c|c|}
\hline & & Gender & Age & Education \\
\hline \multirow{3}{*}{ Perceptions on frequency of crime against visitors } & Chi-square & $3.595 \mathrm{a}$ & $9.972 \mathrm{a}$ & $5.682 \mathrm{a}$ \\
\hline & df & 2 & 6 & 4 \\
\hline & Sig. & .166 & .126 & .224 \\
\hline \multirow{3}{*}{ Perceptions on time of crime against visitors } & Chi-square & $2.403 \mathrm{a}$ & $5.695 \mathrm{a}$ & $.489 \mathrm{a}$ \\
\hline & df & 2 & 6 & 4 \\
\hline & Sig. & .301 & .458 & .975 \\
\hline \multirow{3}{*}{ Perceptions on type of criminal activities } & Chi-square & $6.458 \mathrm{a}$ & $38.603 \mathrm{a}$ & $16.176 \mathrm{a}$ \\
\hline & df & 5 & 15 & 10 \\
\hline & Sig. & .264 & .001 & .095 \\
\hline \multirow{3}{*}{ Visitors affected by crime in Florida Road } & Chi-square & $5.892 \mathrm{a}$ & $2.319 \mathrm{a}$ & $4.678 \mathrm{a}$ \\
\hline & df & 1 & 3 & 2 \\
\hline & Sig. & .015 & .509 & .096 \\
\hline \multirow{3}{*}{ General security in the area and security of visitors } & Chi-square & $5.244 \mathrm{a}$ & $17.190 \mathrm{a}$ & $17.804 \mathrm{a}$ \\
\hline & df & 3 & 9 & 6 \\
\hline & Sig. & .155 & .046 & .007 \\
\hline \multirow{3}{*}{ General safety \& security in Florida Road } & Chi-square & $5.807 \mathrm{a}$ & $15.227 \mathrm{a}$ & $6.549 \mathrm{a}$ \\
\hline & df & 3 & 9 & 6 \\
\hline & Sig. & .121 & .085 & .365 \\
\hline \multirow{3}{*}{ Rate of crime against visitors } & Chi-square & $1.330 \mathrm{a}$ & $5.175 a$ & $2.229 \mathrm{a}$ \\
\hline & df & 2 & 6 & 4 \\
\hline & Sig. & .514 & .522 & .694 \\
\hline \multirow{3}{*}{ Rate of crime in Florida Road as compared to other areas in Durban } & Chi-square & $6.847 \mathrm{a}$ & $3.813 \mathrm{a}$ & $2.707 \mathrm{a}$ \\
\hline & df & 3 & 9 & 6 \\
\hline & Sig. & .077 & .923 & .845 \\
\hline \multirow{3}{*}{ Decline in the number of visitors } & Chi-square & $.020 \mathrm{a}$ & $3.371 \mathrm{a}$ & $.515 \mathrm{a}$ \\
\hline & df & 1 & 3 & 2 \\
\hline & Sig. & .888 & .338 & .773 \\
\hline \multirow{3}{*}{ Perception of safety of Florida Road } & Chi-square & $3.354 \mathrm{a}$ & $5.771 \mathrm{a}$ & $5.909 \mathrm{a}$ \\
\hline & df & 3 & 9 & 6 \\
\hline & Sig. & .340 & .763 & .433 \\
\hline \multirow{3}{*}{ Perceptions that visitors are always targeted by criminals in the area } & Chi-square & $1.940 \mathrm{a}$ & $13.667 \mathrm{a}$ & $11.843 \mathrm{a}$ \\
\hline & df & 3 & 9 & 6 \\
\hline & Sig. & .585 & .135 & .066 \\
\hline \multirow{3}{*}{ Police visibility in the area } & Chi-square & $3.021 \mathrm{a}$ & $10.947 \mathrm{a}$ & $4.189 \mathrm{a}$ \\
\hline & df & 3 & 9 & 6 \\
\hline & Sig. & .388 & .279 & .651 \\
\hline \multirow{3}{*}{ Safety and security warnings for visitors } & Chi-square & $4.269 \mathrm{a}$ & $6.727 \mathrm{a}$ & $4.464 \mathrm{a}$ \\
\hline & df & 4 & 12 & 8 \\
\hline & Sig. & .371 & .875 & .813 \\
\hline \multirow{3}{*}{ The influence of crime in Florida Road } & Chi-square & $1.244 \mathrm{a}$ & $14.012 \mathrm{a}$ & $8.306 \mathrm{a}$ \\
\hline & df & 4 & 12 & 8 \\
\hline & Sig. & .871 & .300 & .404 \\
\hline
\end{tabular}

Results of The Qualitative Study (Interviews with Law-Enforcement Agencies and Business Owners)

This section of the study adopts the qualitative methodology through interviews with 5 key informants from law-enforcement agencies and business owners in Florida Road to add more substance and detail to issues. The rationale for this approach is that the fight against crime in tourism requires leadership, commitment and drive in order to deliver on set goals.

According to Ryan and Kinder (1996) where tourists and criminals converge, there will be a greater exposure to risk and insecurity and, in most cases, there are insufficient numbers of police to ensure the safety of tourists. When interviewing different respondents, majority of them indicated that there are certain crimes which have become so common in the area. The SAPS officials indicated that police officers carry out patrols and are always visible at all times as well as working together with the private security companies in the area and the roadside car-guards as a way of combatting crime against tourist in the area.

The Florida Road community, particularly businesses had to come together for establishment of the Florida Road UIP project in order to tackle the issue of crime against tourists or crimes in general which was officially legislated in July 2013 by eThekwini Municipality (Florida Road UIP 2020). The Florida Road UIP fulfils a vital role by integrating various security entities and resources in the precincts, a key component of which is the UIP Monthly Security Forum attended by private security companies servicing UIP properties and property managers. The aim of the forum is to proactively improve the level of security in the UIP precincts through integration, sharing intelligence, and ensuring operational assistance in emergencies.

Florida Road UIP Operations Manager indicated that the plan is to have CCTV cameras installed at every corner of the street, however the challenge for installing a CCTV system was the costs. The costs for covering the entire road with cameras would be extremely high. Not only would cameras be required at each of 14 intersections and covering the spaces in between, but operators manning the system $24 / 7$ would also be needed. This means a control room for operators and all the equipment that comes with it. As plans to safeguard tourists in the area, the metro police department have already pledged their support of the Florida Road UIP with satellite police station and metro police officers deployed to the area to enforce municipal by-laws. The Florida UIP manager through interview said "there are UIP roadside car-guards along the street and a 24-hour armed response guards patrolling on vehicle and the metro police have joined forces by establishing a satellite office here". A decrease in crime at a destination should be equated with measures to ensure the security and well-being of tourists. 


\section{Results of the Qualitative Study (Focus Group Discussions)}

The objective was to gain insight in order to determine whether the stakeholders such as police and businesses are doing anything to tackle the issues of crime against tourists and to make recommendations to what further can be done to prevent crimes against tourists in Florida Road and the province at large.

The respondents agree that tourists often carry large sums of money or valuable items such as cameras and jewellery when going around which can easily attract criminals. Sometimes tourists do not follow basic crime prevention measures, such as not leaving their property unattended and making sure that car doors and the windows in their hotels are locked. One of the interviewees elaborated further by saying "tourists sometimes engage in activities which may increase their risk of victims of crime, they visit night clubs and bars at late hours and also end up being at unknown parts of the community which might be considered 'unsafe' by local residents".

The economies of this country and the world are not stable so when a certain business has been hit by a crime, that can surely lead to a downfall. One of the interviewees said "Direct losses due to crime and security costs reduce profits and divert funds that could be invested in business infrastructure”. It is very clear that the increased costs for security are a serious financial burden to many businesses. Businesses, police together with the communities need to work together to fight crime in the country.

All stakeholders have joined forces in fight against crime and the UIP roadside car-guards were introduced. "We are dedicated to fighting crime in our community and the roadside car-guards form an integral link between police, security, emergency services and members of the public" said one of the respondents. The Florida Road UIP Manager in a meeting reported that from January to October 2016, a total of 22 suspects were arrested and handed over to SAPS.

Availability of tourist information centre, installation of surveillance cameras at every corner of the street and integration of Community Policing Forum $[\mathrm{CPF}]$ and tourism structures are some of the things they are planning to implement. Florida Road UIP has initiated roadside monitor programme to get rid of vagrants who pose as car guards to carry out criminal activities. The roadside car-guards are seen along the street wearing red and black branded uniform to identify themselves.

The Florida Road UIP also opened up a service kiosk for day time policing. "With the implementation of the roadside car-guards, we then met with the City officials who were supportive enough to secure the presence of Metro police officers in the area" said the UIP manager. He further indicated that his vision would be for the kiosk to be multi-purpose use as an information centre and would be approaching Durban Tourism to have a representative in the kiosk to promote tourism in the area.

\section{Thematic Qualitative Results}

The NVivo software package was used to analyse qualitative data to code and finding connections for thematic analysis of the survey, interview and focus group transcripts by generating themes to address research questions. This software helped to organise and analyse nonnumerical or unstructured data.

The study revealed that there was a decline in visitor number to Florida Road, however the reason for the decline was not motivated by crime incidents in the area. As indicated below on Figure 3, the cause of the decline was due to negative economic conditions as people are no longer able to afford life of eating out.

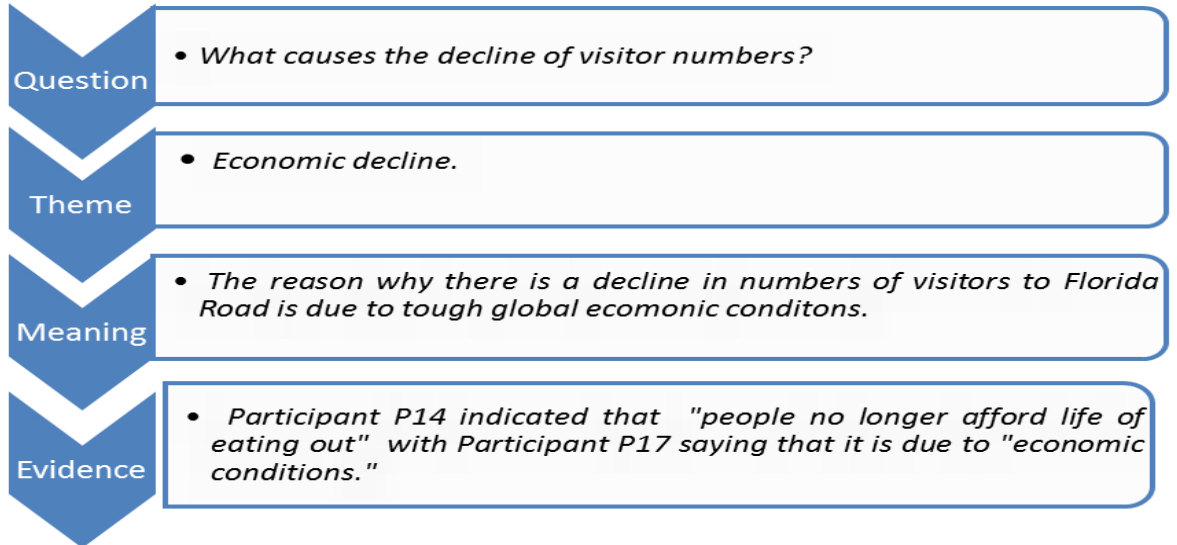

Figure 3. Causes of the decline of visitor numbers

Participant P24's responses on Figure 4 below show that due to crime in the area some businesses are forced to close down. The participant also indicated that there should be more police visibility with quick response and a security cluster involving all stakeholders is required.

\section{CONCLUSION}

The focus of this study has been an investigation in perceptions of crime on tourists eating out at Florida Road in Durban. The perception of crime against tourists shows that crime is controllable and moderate. There is a perception that the number of tourists has decreased in the last three years and the area is currently experiencing high level of theft of motor vehicles and theft out of motor vehicles due to lack of enough police support. The decrease of tourists in the area is believed to have been influenced by the current negative economic conditions as tourists are no longer able to afford eating out at restaurants. The vagrants posing as car guards had criminal records and as a result the UIP roadside car-guards were introduced and the vagrants were chased away. This supports the theories that argue social apathy increases crime, and that more concerted effort by local stakeholders can reduce the risk of crime.

The study did not attempt to interview tourists directly about their fears and experiences because it is difficult to get access to them in the Florida Road restaurants: no hospitality manager would want interviewers disturbing customers with scary questions. However, further research could now be done by more discreet means, such as tracking online reviews of local hospitality offerings, and also, where tourists have gone to the police stations, gaining access to the text of the police reports, if allowed.

Tourists attract criminals by not following basic safety and security measures. They are seen carrying large sums of money and not keeping their valuable items in a safe place. One of the worrying factors is that tourists tend not to report crimes committed against them as 
they do not want to come back to attend court proceedings to avoid return trips and testify against criminals. Tourists fail to pay attention to security issues as they engage themselves in activities which may increase the risk of being victims of crime. There is a need for $24 / 7 \mathrm{CCTVs}$ and roadside monitoring that will help with evidence for convictions. Increased police manpower with regular patrols and the visitor information centre are required in order to improve the safety and security in the study area.

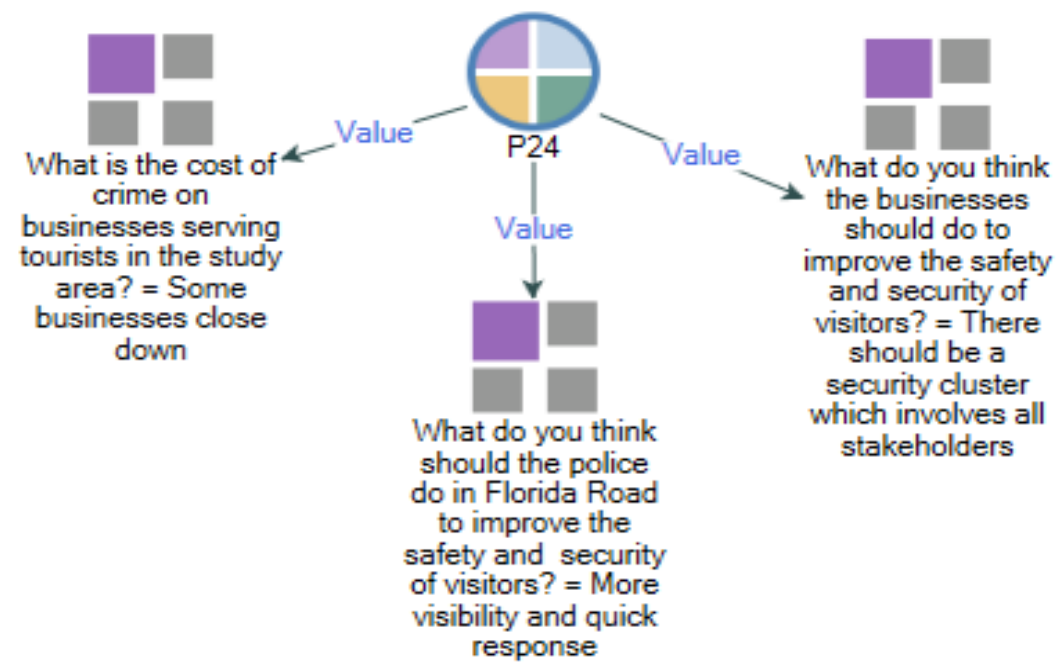

Figure 4. Thematic responses from Participant P24

In Florida Road, there is an improved partnership between public and private investment in security as the UIP through a dedicated security team enables stakeholders such as the police, CPF, private security companies, residents and the business establishments to interact and co-operate in fighting crime against tourists. At the core of Florida Road's success is the ability for the UIP and eThekwini municipality to build and strengthen a mutually beneficial relationship. But realistically the pace at which the proposed security measures can be implemented depends on the financial ability of the business owners and the municipality and SAPS to bear the cost.

Tourism as an industry (worldwide) can choose to make profits and create jobs either by segregated tourism, mostly for rich foreigners, or by enhancing the quality of what is on offer to all, including locals who can afford it. Examples of segregated tourism include, cruise ships, and hotels with private beach fronts and luxury holiday camp brands. In South Africa, it includes safari tours, and luxury trains. These thrive because the way they are managed excludes any intruding locals except those who work there who are carefully screened for criminal records. Recent statistics show the increase of international visitors to South Africa from elsewhere in Africa. Florida Road can be developed into a top tourist destination by investing more resources into some local leisure activities and enhancing security of what is currently on offer in order to attract more locals and increase number of international visitors.

The study concludes that safety and security are important factors to consider for tourism growth as to urists are more likely to choose a destination perceived to be safe. The increase of crime at a tourist destination is related to deeper socio-economic problems. This gives a perception of insecurity that directly or indirectly affects tourist's decision-making process, and the destination choice. In order to ensure crime prevention and tourists are secure at Florida Road, the study recommends that authorities should focus on situational crime prevention measures. The measures which can help tourists' destinations to be safe and risks reduced include physical infrastructures such as police kiosk, as well as surveillance technology at intersections and visible policing. This has been proved to be a successful approach in keeping tourists and major tourist destinations safe during South Africa's hosting of the 2010 FIFA World Cup as security measures were increased significantly.

\section{REFERENCES}

Brás, M. (2015). Tourism and Crime - Why Tourists become Victims. Security \& Tourism: Local Policies and Practices. Maison de L'Europe - European Union, Paris. Conference paper. 25th June 2015, 1-8.

Chainey, S, Tompson, L., \& Uhlig, S. (2008). The utility of hotspot mapping for predicting spatial patterns of crime. Security Journal, 21, 4-28. https://doi.org/10.1057/palgrave.sj.8350066

Cooper, R.D., \& Schindler, S.P. (2001). Business research methods. Singapore. McGraw-Hill International.

Ferreira, S., \& Harmse, A. (2000). Crime and tourism in South Africa: international tourists' perceptions and risk. South Africa Geographical Journal, 82(2), 80-85. https://doi.org/10.1080/03736245.2000.9713696

George, R. (2003). Tourists' Perceptions of Safety and Security while visiting Cape Town. Tourism Management. 24 (3), 575-591. https://doi.org/10.1016/ S0261-5177(03)00003-7

Goodrich, J.N. (2002). September 11, 2001 attack on America: A record of the immediate impacts and reactions in the USA travel and tourism industry. Tourism Management, 23, 573-580. https://doi.org/10.1300/J073v11n04_01

Herbig, F.J.W. (2008). Conservation Crime: South African Concerns and Considerations from a Criminological Perspective. Acta Criminologica, 21 (3), 52-64.

Hermann, U.P., Du Plessis, L., Coetzee, W.J.L., \& Geldenhuys, S. (2012). Socio-economic impacts of the 2010 FIFA World Cup. African Journal for Physical, Health Education, Recreation and Dance, 12 (3), 64-75.

Jacobs, L. (2016). About Florida Road. Sunday Times 14 February, 6.

Levantis, T. \& Gani, A. (2000). Tourism demand and the nuisance of crime. International Journal of Social Economics, 27 , 959-67. https://doi.org/10.1108/03068290010336964

McNabb, D.E. (2002). Research Methods in Public Administration and Non-profit Management. London: M.E. Sharpe Publishers.

Moyo, B. \& Akanbi, O.A. (2013). Crime and the Regional Disparities in Tourist Inflows: A Case Study of South Africa. Journal of Economics and Behavioral Studies Vol. 5, No. 6, June 2013, 356-375. https://doi.org/10.22610/jebs.v5i6.411

Nkosi, S.G. (2010). The impact of crime on tourism in the City of uMhlathuze, Kwa-Zulu Natal. South Asian Journal of Tourism and Heritage Studies, 3(2): 76-81. 
Perry, E.C., Chunderduth, A., \& Potgieter, C. (2012). Securing South Africa during the 2010 FIFA World Cup: Legacy implications for post-event safety and security. African Journal for Physical, Health Education, Recreation and Dance, September (1), 123-130.

Perry, E.D., \& Potgieter, C. (2013). Crime and tourism in South Africa. Journal of Human Ecology, 43(1), 101-111. https://doi.org/10. 1080/09709274.2013.11906616

Phori, M.M. (2017). The impact of crime on tourism in South Africa. Department of Tourism Management. Tshwane University of Technology, 1-125.

Pizam, A. (1999). A comprehensive approach to classifying acts of crime and violence at tourist destinations. Journal of Travel Research, 38(1), 5-12. https://doi.org/10.1177/004728759903800103

Ryan, C., \& Kinder, R. (1996). The deviant tourist and the crimogenic place - The case of the tourist and the New Zealand prostitute. In tourism, crime and international security issues. A. Pizam and Y. Mansfield, Eds., New York: Wiley, 23-36.

Sampson, Robert J., \& Groves, W.B. (1989). Community structure and crime: Testing social-disorganization theory. American Journal of Sociology, 94, no. 4: 774-802. https://doi.org/10.1086/229068

Shaw, C.R., \& McKay H.D. (1942). Juvenile delinquency and urban areas. University of Chicago Press, Chicago, Illinois.

Shaw, C.R.R., \& McKay, H.D. (1969). In Juvenile delinquency and urban areas: A study of rates of delinquency in relation to differential characteristics of local communities in American cities (Rev. Ed.). Chicago: University of Chicago Press.

Sherman, L.W., \& Weisburd, D.L. (1995). General deterrent effects of police patrol in crime hot spots: A randomized controlled trial. Justice Quarterly 12:625-648. https://doi.org/10.1080/07418829500096221

Sherman, L.W, Gartin, P.R., \& Buerger, M.E. (1989). Hot spots of predatory crime: Routine activities and the criminology of place. Criminology, $27,27-55$. https://doi.org/10.1111/j.1745-9125.1989.tb00862.x

Sönmez, S.F., \& Graefe, A.R. (1998). Influence of terrorism risk on foreign tourism decisions. Annals of Tourism Research, 25(1), 112-144. https://doi.org/ 10.1016/S0160-7383(97)00072-8

*** South African Tourism. (2013). Annual Performance Plan Final. 2013/2014. Johannesburg, South Africa.

*** South African Tourism. (2017). Annual Performance Plan Final. 2016/2017. Johannesburg, South Africa.

*** Statistics South Africa. (2015). Victims of Crime Survey, 2014/15. Pretoria, South Africa.

*** Africa Check. (2020). Factsheets \& Guides (Online). Available: https://africacheck.org/factsheets/factsheet-south-africas-official-crime-statistics- for201314 (Accessed 08 March 2020).

*** Business Tech. (2020). South African crime stats. (Online). Available: https://businesstech.co.za/news/government/270689/south-africa-crime-stats2020-everything-you-need-to-know, (Accessed 03 April 2020).

*** Florida Road UIP. (2020). Florida Road UIP 2014 Annual report (online). Available: URL:http://floridaroaduip.co.za/wpnews/wp-content/uploads/bskpdf-manager/27_FLORIDA_RD_UIP_ANNUAL_REPORT_FOR_YEAR_ENDING_20_JUNE_2014_AND_AGM_NOTICE.PDF Accessed 18 April 2020.

*** Florida Road UIP. (2020). Why A UIP (online). Available: http://floridaroaduip.co.za/why-a-uip.php. Accessed 19 April 2020.

*** Florida Road. (2020). Florida Road UIP Annual Report (online). Available: http://floridaroaduip.co.za/wpnews/wp-content/uploads/bsk-pdf-manager/72 _DECEMBER_2015_FLORIDA_RD_UIP_ANNUAL_REPORT_FOR_YEAR_ENDING_30_JUNE_2015.PDF. Accessed 17 April 2020.

*** South African Tourism. (2020). Florida Road (online). Available: $\quad$ http://www.southafrica.net/za/en/articles/entry/article-florida-road. Accessed 03 April 2020.

Article history: Received: $31.03 .2020 \quad$ Revised: $23.06 .2020 \quad$ Accepted: 08.09.2020 Available online: 29.09.2020

